\title{
Article \\ Fabrication and Biodegradability of Starch Cell-Plastics as Recyclable Resources
}

\author{
Akihito Nakanishi ${ }^{1,2, *,+} \mathbb{0}$, Kohei Iritani ${ }^{3,+}$, Yuri Sakihama ${ }^{4}$, Marina Watanabe ${ }^{1}$, Ayano Mochiduki ${ }^{1}$, \\ Akane Tsuruta ${ }^{1}$, Syunta Sakamoto ${ }^{5}$ and Ayami Ota ${ }^{3}$ \\ 1 School of Bioscience and Biotechnology, Tokyo University of Technology, Tokyo 192-0982, Japan; \\ b01173031e@edu.teu.ac.jp (M.W.); b011726155@edu.teu.ac.jp (A.M.); b01181807d@edu.teu.ac.jp (A.T.) \\ 2 Graduate School of Bionics, Tokyo University of Technology, Tokyo 192-0982, Japan \\ 3 School of Engineering, Tokyo University of Technology, Tokyo 192-0982, Japan; iritanikh@stf.teu.ac.jp (K.I.); \\ e7117015ef@edu.teu.ac.jp (A.O.) \\ 4 Tokyo University of Technology, Tokyo 192-0982, Japan; re19001b6@edu.teu.ac.jp \\ 5 Graduate School of Engineering, Tokyo University of Technology, Tokyo 192-0982, Japan; \\ g512001582@edu.teu.ac.jp \\ * Correspondence: nakanishiah@stf.teu.ac.jp \\ + Co-first author.
}

check for updates

Citation: Nakanishi, A.; Iritani, K.; Sakihama, Y.; Watanabe, M.; Mochiduki, A.; Tsuruta, A.; Sakamoto, S.; Ota, A. Fabrication and Biodegradability of Starch Cell-Plastics as Recyclable Resources. Appl. Sci. 2021, 11, 847. https:// doi.org/10.3390/app11020847

Received: 25 December 2020

Accepted: 14 January 2021

Published: 18 January 2021

Publisher's Note: MDPI stays neutral with regard to jurisdictional claims in published maps and institutional affiliations.

Copyright: (c) 2021 by the authors. Licensee MDPI, Basel, Switzerland. This article is an open access article distributed under the terms and conditions of the Creative Commons Attribution (CC BY) license (https:// creativecommons.org/licenses/by/ $4.0 /)$.

\begin{abstract}
Recently, cell-plastics, which are composed of unicellular green algal cells and biodegradable compounds as ingredients and fillers, have been suggested as carbon-recyclable materials instead of petroleum-based plastics. In this study, cell-plastics, fabricated with Chlamydomonas reinhardtii as an ingredient and a mixture of two types of starches (raw and oxidized starches) as a filler, were successfully stabilized as independent structures despite the quantity of algal cells being nine times more than that of starch. All starch cell-plastics were water repellent, possibly due to their bumpy surface structures. The starch cell-plastic, composed of 50\% cells and 50\% starch (1.5:1 of oxidized starch versus raw starch), showed $327 \pm 52 \mathrm{MPa}$ as Young's modulus and $6.45 \pm 1.20 \mathrm{MPa}$ as tensile strength, indicating the possibility to be a suitable replacement for petroleum-based plastics. Additionally, all starch cell-plastics showed water-repellency and maintained those structures dipped in phosphate-buffered saline buffer as a water environment for $24 \mathrm{~h}$, meaning that all starch cell-plastics had evaluable water resistance. On the other hand, by adding $\alpha$-amylase, all starch cell-plastics were collapsed and lost the weight efficiently, indicated their biodegradability. This is the first paper to describe starch cell-plastics from their fabrication to biodegradation.
\end{abstract}

Keywords: cell-plastics; biodegradability; unicellular green alga; green plastics

\section{Introduction}

Plastics are widely used in various domestic and industrial fields, making them essential for maintaining global economic activities [1]. Despite the recent emphasis on the creation of a sustainable society, 99\% of plastics are made from petroleum, which means that the plastic industries depend on petroleum resources [2]. Dependence on petroleum resources is subject to various problems such as depletion of finite petroleum resources, environmental pollution during petroleum refining [3-5], and increase in the $\mathrm{CO}_{2}$ concentration in the atmosphere [6], necessitating urgent development of alternative resources on a global scale. Due to escaping from petroleum-use, many studies have advocated green plastics by using biomass derived from $\mathrm{CO}_{2}$ as recyclable resources [7-9]. Among the many bioplastics, biodegradable bioplastics are especially attractive as nextgeneration carbon-recyclable plastics [10-12]. However, bioplastics have hardly been used due to their expensive production process. Therefore, bioplastics, which have scope for cost reduction, especially in the extraction and purification processes, are being increasingly considered [13]. 
Recently, cell-plastics have been suggested as new raw materials $[12,14,15]$. Cellplastics are bioplastics constructed of unicellular green algal cells, such as Chlamydomonas reinhardtii, as ingredients and biodegradable compounds such as glycerol, bovine serum albumin (BSA), and polybutylene succinate (PBS) as fillers. Cell-plastics have several properties as follows: (1) green algae such as Chlamydomonas sp., which have a higher carbon assimilating ability than general terrestrial plants, are used as ingredients, resulting in easier preparation as a biomass resource [16]; (2) these cells are substantially rigid [17], providing cell-plastics with the requisite strength as a raw material; (3) there is no need to extract and refine the cell components as the end product because the cells can be directly used; and (4) unicellular cells can be freely placed and a filler can be used to connect each cell. Various cell-plastics have been fabricated so far, with cell-plastics composed of PBS exhibiting a tensile strength of $8.8 \pm 3.8 \mathrm{MPa}$ and a Young's modulus of $240 \pm 90 \mathrm{MPa}$ [14], similar to the properties of low-density polyethylene (LDPE), which has a Young's modulus of 165.3 MPa and a tensile strength of 10.3 MPa [18]. The mechanical characteristics of the PBS cell-plastics suggested its potential as a substitute to polypropylene (PP) and polyethylene (PE), which have a high demand and constitute $\sim 92 \%$ of plastics produced from petroleum, such as wrapping and sheets used as commodities [19]. Although these cell-plastics are fabricated using biodegradable cells and fillers, their degradation has not been studied. Therefore, the biodegradability of cell-plastics as carbon-recyclable bioplastic resources needs to be proven.

In this study, cell-plastics were fabricated using the unicellular green alga C. reinhardtii as an ingredient and starches as fillers. Raw starch is hydrophilic; therefore, its use is restricted to producing practical plastics because of its non-waterproof nature, unlike general plastics. In a previous study, PBS cell-plastics composed by adding cells into PBS showed enhanced water repellency than that displayed by PBS, presumably due to the lotus effect [14]. Thus, for the fabrication of starch cell-plastics, water repellency was expected by adding algal cells. Additionally, enhanced water repellency was achieved by using oxidized starch to control its hydrophilic property by changing the hydroxyl group to a carbonyl group in raw starch [20]. Next, cell-plastics were fabricated according to modification of contents as follows: (1) the ratio of the ingredient and the filler; and (2) the ratio of raw starch and oxidized starch. The fabricated cell-plastics were analyzed for their surface characteristics using scanning electron microscopy (SEM), mechanical characteristics using tensile tests, and biodegradability using $\alpha$-amylase. Although the biodegradation of starch by $\alpha$-amylase is well known [21], the biodegradation of starch cell-plastics has not been proven yet. This is the first report to describe starch cell-plastics from their fabrication to biodegradability and to introduce their potential as recyclable carbon resources.

\section{Materials and Methods}

\subsection{Microalgal Strain and PBR Operation}

Chlamydomanas reinhardtii strain C-9: NIES-2235 was cultured in modified Bold $6 \mathrm{~N}$ medium $(\mathrm{MB} 6 \mathrm{~N})$ with a photobioreactor system at room temperature $\left(23^{\circ} \mathrm{C}\right)$ as described in a previous study [22]. The photobioreactor was equipped with a bubbling system of $0.8 \% \mathrm{CO}_{2}$ gas at an aeration rate of $0.05 \mathrm{vvm}$, white fluorescent lamps $(100 \mu \mathrm{mol}$ photons $\left.\cdot \mathrm{m}^{-2} \cdot \mathrm{s}^{-1}\right)$.

\subsection{Evaluation of Culturing Condition}

Cell number was evaluated for cell growth with $\mathrm{OD}_{750}$ value via appropriate calibration curve for $\mathrm{OD}_{750}$ versus cell numbers by using a spectro-photometer U-2900 (Hitachi, Tokyo, Japan) [23]. Culturing pH was measured with pH meter FEP20 (Mettler Toledo, Tokyo, Japan) after centrifugation at $5000 \times g$ for $1 \mathrm{~min}$ at $23^{\circ} \mathrm{C}$ [24]. Nitrate concentration was measured using an optical method. The broth was centrifuged at $5000 \times g$ for $1 \mathrm{~min}$ at $23{ }^{\circ} \mathrm{C}$, and the supernatant was filtered with a $0.45 \mu \mathrm{m}$ filter (Millex ${ }^{\circledR}-\mathrm{LCR} 13 \mathrm{~mm}$, Millipore, Carrigtwohill, Ireland). The flow through was diluted 50-fold with distilled 
water, and the absorbance of the diluted supernatant was measured at $220 \mathrm{~nm}$ (i.e., $\mathrm{Abs}_{220}$ ) with a spectro-photometer U-2900. The residual nitrate content was evaluated with an appropriate calibration curve for $\mathrm{Abs}_{220}$ versus nitrate concentration [16].

\subsection{Fabrication of Starch Cell-Plastics}

C. reinhardtii cells before nitrogen depletion were harvested by centrifugation at $5000 \times$ $g$ for $1 \mathrm{~min}$ at $23^{\circ} \mathrm{C}$; starch and oxidized starch were provided by Matsutani Chemical Industry Co., Ltd. (Hyogo, Japan). Oxidized starch is a polymer obtained by treating raw starch with hypochlorous acid resulting in the hydroxy group changing to a carboxyl group via oxidation. Raw starch and oxidized starch were prepared to make 0.5:1, 1:1 and 1.5:1 of oxidized starch weight versus starch weight before mixing starch with cells. After the starch preparation, the cells as ingredients and the prepared starches as fillers were mixed to adjust the ratio of $0 \%, 50 \%$ and $90 \%$ based on cell-weight versus total weight.

\subsection{Scanning Electron Microscopy}

Starch cell-plastics were coated with Au particles using an ion coater (IB-2; Eiko Engineering, Tokyo, Japan) before scanning. The Au particle-coated cell-plastics were observed with SEM (JSM-6060LV; Japan Electron Optics Laboratory Co., Ltd., Tokyo, Japan).

\subsection{Evaluation of Young's Modulus and Tensile Strength}

The starch cell-plastics were analyzed for evaluating the Young's modulus and tensile strength with a tensile strength tester (TesTex, Zurich, Switzerland) $[14,15,25]$. The cell-plastics were prepared into rectangles and the evaluating area was $5 \times 7.5 \mathrm{~mm}$. A crosshead rate of $1.00 \mathrm{~mm} \cdot \mathrm{min}^{-1}$ was maintained. Under analyzing the test-samples, a load-displacement curve was plotted. To calculate the Young's modulus and tensile strength, a stress-strain curve was plotted by dividing the load and displacement by the cross-section and the initial length of the test piece, respectively. The thickness of the cell-plastics was evaluated by the SEM observations of the small sample pieces cut using scissors. Young's modulus was derived using the slope of an initial straight line approximated via the least squares method. The tensile strength was defined as the maximum stress value. The Young's modulus and tensile strength of each film were the averages of 3 test pieces obtained by cutting three different films into three different-sized areas.

\subsection{Water Repellent Evaluation Test}

Drop Master 300 (Kyowa Interface Science Co., Ltd., Saitama, Japan) was used to evaluate the contact angle. The contact angle was determined after depositing a drop of water on the films.

\subsection{Evaluation of Biodegradation-Activity with $\alpha$-Amylase}

$\alpha$-Amylase was purchased from Fuji Film Wako Pure Chemical Corp. (Osaka, Japan). One $\mathrm{g} \mathrm{mL}^{-1} \alpha$-amylase solution was prepared with phosphate-buffered saline $(\mathrm{pH}=7.4)$. Starch cell-plastics and starches were treated with $1 \mathrm{~mL}$ of $\alpha$-amylase solution at $23^{\circ} \mathrm{C}$ (room temperature) for $24 \mathrm{~h}$. After the treatment, the reactants were centrifuged at $5000 \times$ $g$ for $3 \mathrm{~min}$ at $23^{\circ} \mathrm{C}$; the supernatants were discarded and the residues were collected as the precipitate. The precipitates were weighted to evaluate degrading activity to starch cell-plastics and starches. The $\alpha$-amylase degrading activity was shown as the calculated value as below: $\mathrm{i}$, degradation with $\alpha$-amylase, $100 \times($ (initial weight $(\mathrm{g})-$ residual weight (g))/initial weight $(\mathrm{g}))$; ii, degradation without $\alpha$-amylase, $100 \times(($ initial weight (g) - residual weight $(\mathrm{g})$ )/initial weight (g)); iii, $\alpha$-amylase degradation activity, the value obtained in $\mathrm{i}-$ the value obtained in ii. 


\section{Results and Discussion}

In this study, starch cell-plastics were prepared by mixing varying ratios of C. reinhardtii cells and starches as well as by mixing ratios of raw starch and oxidized starch (Figure 1). All starch cell-plastics fabricated using variable ratios of cells versus starches and of raw starch versus oxidized starch could successfully maintain their self-standing structures. In a previous research, PBS cell-plastics composed of 3:1 cells to PBS ratio could not stably maintain the structure because of the loss of powder-like particles on the surface [14]. However, starch cell-plastics sustained their structures even when composed of ingredient cell content nine times more than starch content. The result was majorly attributable to the good mix of cells and fillers because of their hydrophilic properties, unlike PBS, which is hydrophobic.
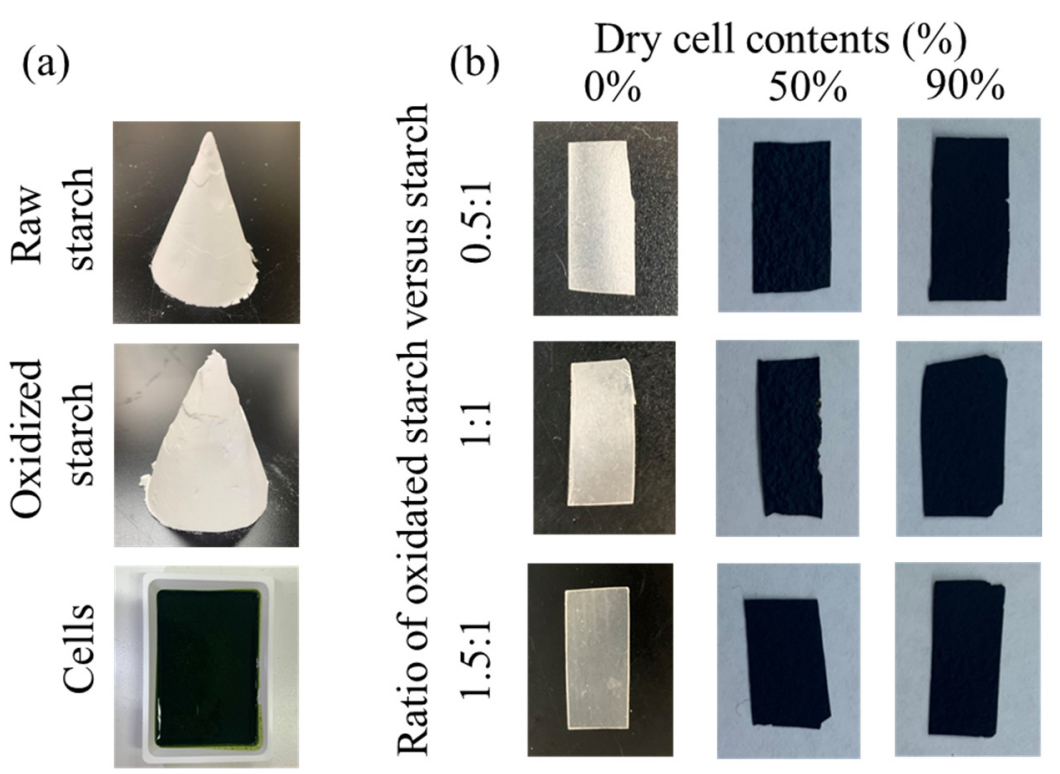

Figure 1. Pictures of starch cell-plastics, starch and cells. (a) Components of starch cell-plastics. (b) Starch cell-plastics.

The structures of the surface and cross-section of the starch cell-plastics were visually evaluated via SEM (Figure 2). The starches used as control displayed smooth surfaces and packed cross-sections, even with different component ratios of raw and oxidized starch. The pasted starch formed a structure similar to that of a smooth film (Figure 1) such that the results of SEM observation had sufficient validity. On the other hand, all starch cell-plastics displayed particle structures, presumably composed of cells on their surfaces, and packed cross-sections, although the cross-sectional structures were bumpy, presumably formed by cells. There was no correlation between the ratios of raw and oxidized starch. As shown in Figures 1 and 2, the differences between previous PBS cell-plastics and starch cell-plastics clearly lie in the filler spreading among the ingredient cells. Although the unstable structures of PBS cell-plastics were confirmed under the fabrication condition of $75 \%$ or more composition of $C$. reinhardtii cells, all starch cell-plastics, even under the fabrication condition of $90 \%$ of $C$. reinhardtii cells could maintain their packed structures. For the fabrication of PBS cell-plastics, the hydrophilic cells were forcibly mixed with PBS in hydrophobic dichloromethane; on the other hand, for starch cell-plastics, the cells were mixed with starches in water. In the case of starch cell-plastics, packed structures could be explained by the fact that cells and starches easily combined under hydrophilic conditions. 


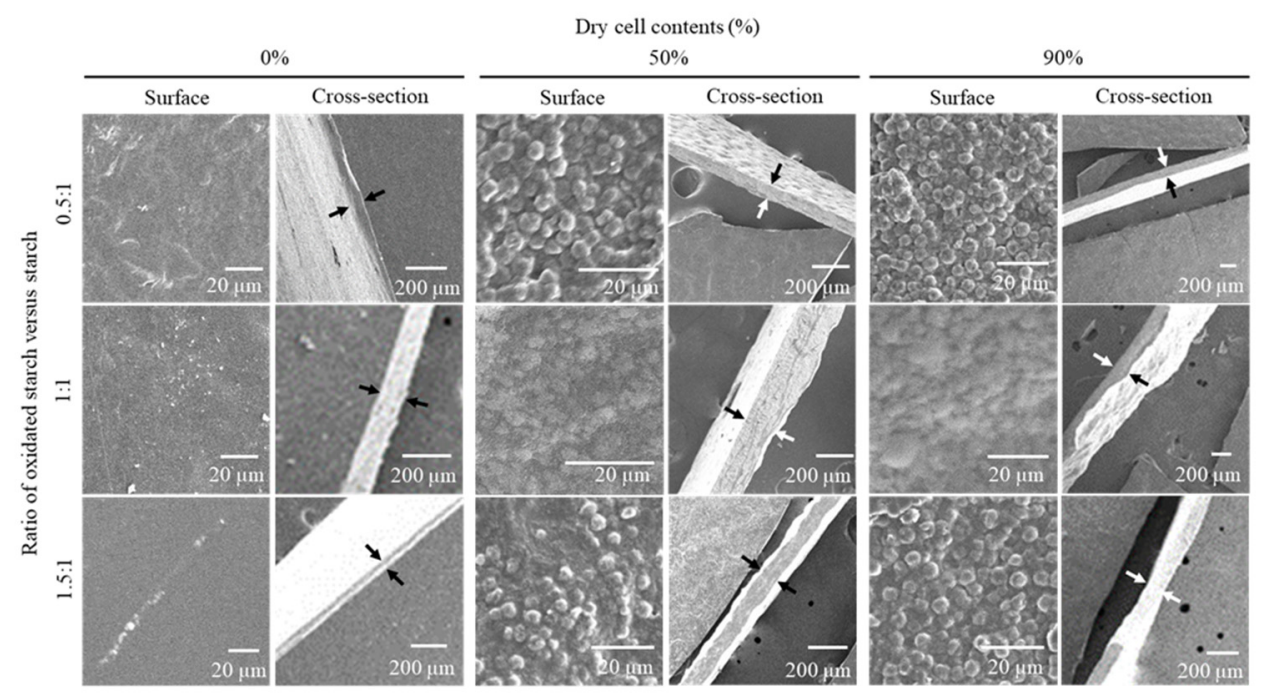

Figure 2. SEM images of surfaces and cross-sections of starch cell-plastics and starches, respectively. The white and black arrows show the thickness of those cross-sections. The white lines are inserted as scale bars.

Tensile tests were conducted to evaluate the mechanical properties of the starch cellplastics (Figures 3 and 4). As seen in the stress-strain curve (S-S curve) in Figure 3, all starches, irrespective of the ratios between raw and oxidized starch, immediately fractured after reaching their maximum tensile strength. Due to sudden rupture without observable structural glide, the starch cell-plastics also immediately fractured after reaching their maximum tensile strength. These rupturing properties did not depend upon the ratio of raw starch to oxidized starch. The starches showed Young's modulus of $566 \pm 249 \mathrm{MPa}$ in 0.5 oxidized starch: 1 raw starch, $279 \pm 30 \mathrm{MPa}$ in 1 oxidized starch: 1 raw starch, and $187 \pm 37 \mathrm{MPa}$ in 1.5 oxidized starch: 1 raw starch, respectively (Figure 4). The decreasing values of Young's modulus related to the increasing ratio of oxidized starch, indicating a negative correlation between Young's modulus and the ratio of oxidized starch. The hydroxy group of starch was changed to a carboxyl group via oxidation. Therefore, it is possible that the hydrogen bonds between the polymer chains along with the chain length decreased, resulting in a decline in the intermolecular force. Regardless of the ratio of raw starch and oxidized starch, starch cell-plastics composed of $90 \%$ of cells tended to show a lower Young's modulus value than those composed of $50 \%$ of cells. In the case of the starch cell-plastics composed of $90 \%$ of cells rather than $50 \%$, the structures could be strained because the bond between the unicellular $C$. reinhardtii cells as ingredients could be decreased due to the reduced amount of starches as fillers to connect the cells. Likewise, the same trend regarding the cell-contents was observed even for tensile strength (Figure $4 \mathrm{~b}$ ). Regardless of the ratios of the raw and oxidized starches, the tensile strength decreased with increase in percentage of cell components. The results also indicated that the influence of fillers as cell connectors could be decreased by increasing the cell components. The starch cell-plastics ( $0.5: 1$ of oxidated starch versus raw starch; $0 \%$ and $50 \%$ of cells) were collapsible rather than others so that the Young's modulus and tensile strengths were not steady as shown error bars, respectively. The results indicated that the steady-use of the cell-plastics could need the blending balance of cells and starches. In this study, the Young's moduli of the starch cell-plastics composed of $50 \%$ cells were approximately $330 \mathrm{MPa}$ (the ratios of oxidized and raw starches were 0.5:1, 1:1, and 1.5:1, with a Young's modulus value of 327, 340, and $327 \mathrm{MPa}$, respectively). Note that, in the previous research, the Young's modulus value of PBS cell-plastics composed of $50 \%$ cells was $240 \mathrm{MPa}$ [14]. It was revealed that all starch cell-plastics composed of $50 \%$ cells have a higher Young's modulus value than that of LDPE, which is $165 \mathrm{MPa}$ [18]. 


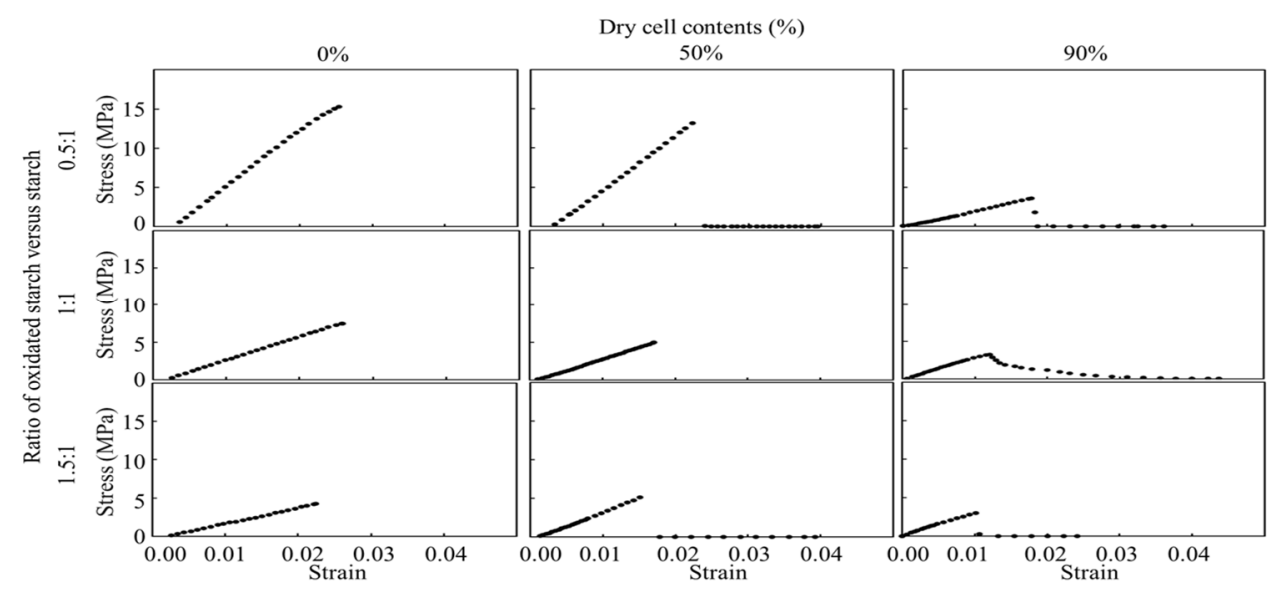

Figure 3. Analysis of stress-strain curves for each starch cell-plastic.
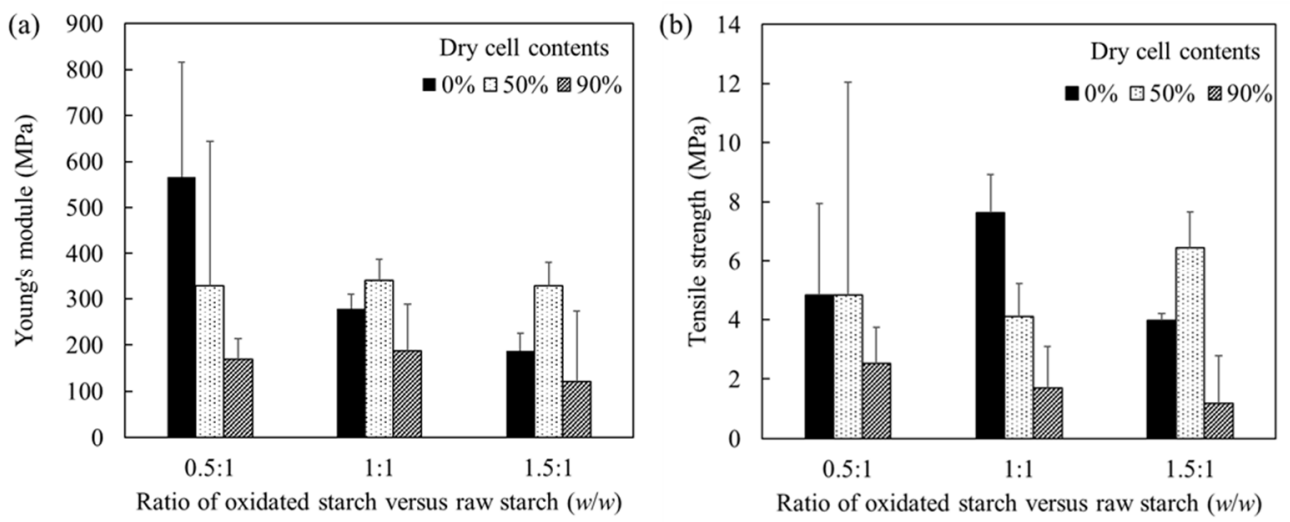

Figure 4. Evaluation of tensile strength test for each starch cell-plastic. (a) Comparison of Young's modulus; (b) comparison of tensile strength. Values are the averages of three replicated experiments, \pm SD.

Water repellency is an important property of plastics. The water repellent properties of the starch cell-plastics and starches were evaluated (Figure 5) by placing water droplets on films of cell-plastics and starches. In the case of starch-film composed of oxidized and raw starch in the ratio of $0.5: 1$, the film could not keep the water droplet and lost its form after water absorbance. On the other hand, starch-films composed of oxidized and raw starch in the ratio of 1:1 and 1.5:1 demonstrated water repellency, indicating that increasing the ratio of oxidized starch could endow the water repellency to starch-film owing to the decrease in hydroxy groups. Instead of increasing the ratio of oxidized starch, adding cells to the starch imparted water repellency. The starch cell-plastics, which were composed of cells (50\% and 70\%) and starch (oxidized and raw starch in the ratio of 0.5:1), showed the water-repellency, indicating that the water repellency could be derived from bumpy surface occurred by adding cells. As seen in the SEM images in Figure 2, all cell-plastics have bumpy surfaces derived from cells. Interestingly, the water repellency of previous PBS cell-plastics was caused by the bumpy surfaces arising from the cells demonstrating the lotus effect. Thus, starch cell-plastics could efficiently exhibit the lotus effect due to the bumps on their surfaces. 


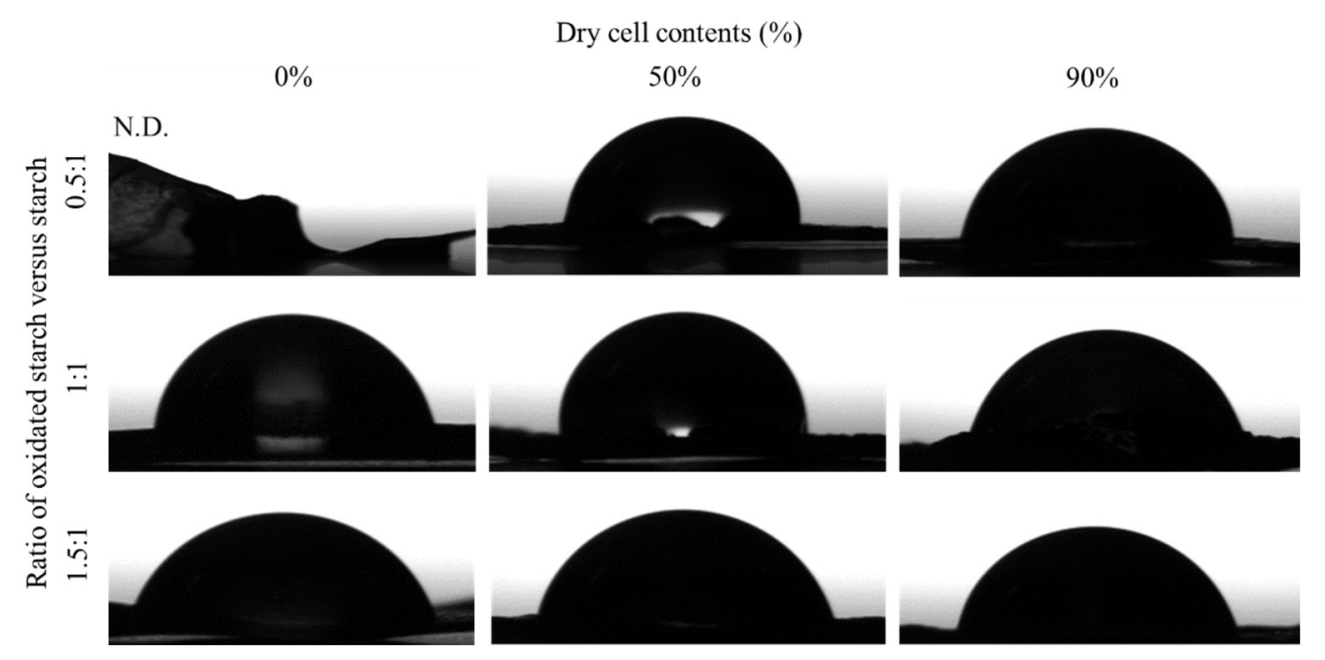

Figure 5. Evaluation of water repellency of each starch cell-plastic.

To ascertain their carbon recyclability, starch cell-plastics needed to be subjected to biodegradation by using degradation systems found in nature. As shown in Figure 6, the biodegradability of starch cell-plastics was evaluated using $\alpha$-amylase, which universally exists in nature. In Figure 6a, although the starch cell-plastics and starches were crumbled with $\alpha$-amylase-treatment, those could maintain the structure without $\alpha$-amylase-treatment. Additionally, the treated cell-plastics could not be grasped because of being collapsed; however, the non-treated cell-plastics could be grasped and bent. Those results indicated that the starch cell-plastics have an evaluable water-resistance dipping in a water environment for $24 \mathrm{~h}$. Therefore, the starch in the cell-plastics could maintain those structures even though those lost the weights in the water. On the other hands, all starch cell-plastics collapsed after treatment with $\alpha$-amylase (Figure 6a). To detect the effect of $\alpha$-amylase on starch cell-plastics in detail, degradation activities without $\alpha$-amylase were compared with the degradation activity of $\alpha$-amylase. Approximately $13-33 \%$ of the weight of the starch cell-plastics and the starches decreased in phosphate buffered saline without $\alpha$-amylase for $24 \mathrm{~h}$ (Figure 6b), whereas with $\alpha$-amylase, there was an additional decrease in these weights in phosphate buffered saline after $24 \mathrm{~h}$. The ratios of weight losses with $\alpha$-amylase could be tentatively related to the ratios of starch content, meaning that the losses were derived from the degradation of starch by $\alpha$-amylase. Although starch cell-plastics exhibited water repellency only briefly, these plastics could be efficiently collapsed with $\alpha$-amylase within a short span of time, i.e., $24 \mathrm{~h}$. Generally speaking, $\alpha$-amylase decomposes starch to low length of starch such as dextrin so that $\alpha$-amylase could possibly attack to degrade mainly starch in starch cell-plastics to low length of starch. Eventually, the collapse of starch in starch cell-plastics could release the components of those plastics. In nature, the green algae are degraded so the released green algal cells could be also degraded. 
(a) Ratio of oxidated starch versus raw starch $(w / w)$

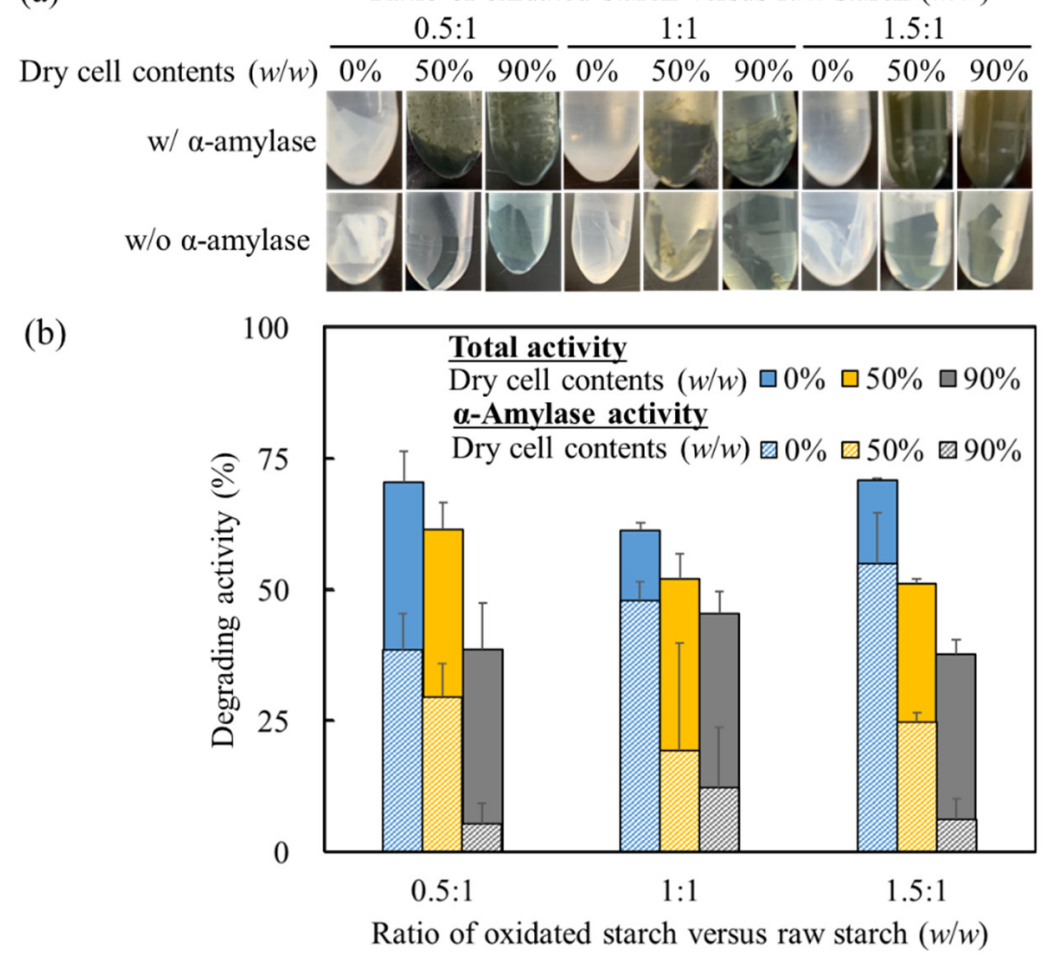

Figure 6. Evaluation of biodegradation of starch cell-plastics with amylase, displaying (a) visualized images of starch cell-plastics and starch after $24 \mathrm{~h}$ treatment, and (b) degrading activities for starch cell-plastics. Values are the averages of three replicated experiments, $\pm \mathrm{SD}$.

\section{Conclusions}

In this study, cell-plastics were fabricated using the unicellular green alga C. reinhardtii as an ingredient and starches as fillers. By using starches as fillers, these starch cell-plastics could stably maintain their structures even when composed of a 9:1 cells to starch ratio. SEM evaluation revealed that all starch cell-plastics had rough structures formed by the cells on the surface. The mechanical characteristics of starch cell-plastics evaluated via tensile testing, showed that starch cell-plastics composed of 50\% cells and 50\% starches (1.5 oxidized starch: 1 raw starch) possessed a higher Young's modulus value than that of PBS cell-plastics. Additionally, these starch cell-plastics were biodegradable even in phosphate buffered saline, which boosted the degradation by $\alpha$-amylase. This is the first paper to evaluate starch cell-plastics right from their fabrication to biodegradation.

Author Contributions: Conceptualization, A.N., K.I. and Y.S.; methodology, A.N., K.I., M.W., A.M., A.T., S.S. and A.O.; validation, A.N. and K.I.; formal analysis, A.N., K.I., A.M., A.T., S.S. and A.O.; investigation, A.N., K.I., A.M., A.T., S.S. and A.O.; resources, A.M. and A.T.; writing-original draft preparation, A.N. and K.I.; writing-review and editing, A.N. and K.I.; visualization, A.N. and K.I.; supervision, A.N.; project administration, A.N. and K.I.; funding acquisition, A.N. and K.I. All authors have read and agreed to the published version of the manuscript.

Funding: Feasibility Study Program of the New Energy and Industrial Technology Development Organization (NEDO).

Institutional Review Board Statement: Not applicable.

Informed Consent Statement: Not applicable.

Data Availability Statement: Data are contained within the article. 
Acknowledgments: The authors would like to thank Yoshihisa Tanaka for technical support. Raw starch and oxidized starch were kindly provided by Matsutani Chemical Industry Co., Ltd. This work was supported by the Feasibility Study Program of the New Energy and Industrial Technology Development Organization (NEDO).

Conflicts of Interest: The authors declare they have no competing interests.

\section{Abbreviations}

BSA: bovine serum albumin; LDPE: low-density polyethylene; PBS: polybutylene succinate; SEM: scanning electron microscopy; S-S curve: stress-strain curve.

\section{References}

1. Geyer, R.; Jambeck, J.-R.; Law, K.-L. Production, use, and fate of all plastics ever made. Sci. Adv. 2017, 3, e1700782. [CrossRef] [PubMed]

2. Ciel. Fueling Plastics 2017 Fossils, Plastics, and Petrochemical Feedstocks. Available online: https://www.breakfreefromplastic. org/bffp_reports/fossils-plastics-and-petrochemical-feedstocks / (accessed on 25 December 2020).

3. Shahbaz, M.; Nasreen, S.; Ling, C.-H.; Sbia, R. Causality between trade openness and energy consumption: What causes what in high, middle and low income countries. Energy Policy 2014, 70, 126-143. [CrossRef]

4. Yao, X.; Yasmeen, R.; Padda, I.-U.-H.; Shah, W.-U.-H.; Kamal, M.-A. Inequalities by energy sources: An assessment of environmental quality. PLoS ONE 2020, 15, e0230503. [CrossRef] [PubMed]

5. Sun, L.; Ruan, J.; Lu, M.; Chen, M.; Dai, Z.; Zuo, Z. Combined effects of ocean acidification and crude oil pollution on tissue damage and lipid metabolism in embryo-larval development of marine medaka (Oryzias melastigma). Environ. Geochem. Health 2019, 41, 1847-1860. [CrossRef] [PubMed]

6. Emadian, S.-M.; Onay, T.-T.; Demirel, B. Biodegradation of bioplastics in natural environments. Waste Manag. 2017, 59, 526-536. [CrossRef] [PubMed]

7. Peelman, N.; Ragaert, P.; de Meulenaer, B.; Adons, D.; Peeters, R.; Cardon, L.; Impe, F.-V.; Devlieghere, F. Application of bioplastics for food packaging. Trends Food Sci. Technol. 2013, 32, 128-141. [CrossRef]

8. Adhikari, D.; Mukai, M.; Kubota, K.; Kai., T.; Kaneko, N.; Araki, K.S.; Kubo, M. Degradation of bioplastics in soil and their degradation effects on environmental microorganisms. J. Agric. Chem. Environ. 2016, 5, 23-34. [CrossRef]

9. Rhim, J.-W.; Park, H.-M.; Ha, C.-S. Bio-nanocomposites for food packaging applications. Prog. Polym. Sci. 2013, 38, 1629-1652. [CrossRef]

10. Folino, A.; Karageorgiou, A.; Calabrò, P.-S.; Komilis, D. Biodegradation of wasted bioplastics in natural and industrial environments: A review. Sustainability 2020, 12, 6030. [CrossRef]

11. Calabrò, P.-S.; Folino, A.; Fazzino, F.; Komilis, D. Preliminary evaluation of the anaerobic biodegradability of three biobased materials used for the production of disposable plastics. J. Hazard. Mater. 2020, 390, 121653. [CrossRef]

12. Nakanishi, A.; Iritani, K.; Sakihama, Y. Developing neo-bioplastics for the realization of carbon sustainable society. J. Nanotechnol. Nanomater. 2020, 1, 72-85.

13. Moroni, M.; Lupo, E.; Pelle, V.; Pomponi, A.; Marca, F. Experimental investigation of the productivity of a wet separation process of traditional and bio-plastics. Separations 2018, 5, 26. [CrossRef]

14. Nakanishi, A.; Iritani, K.; Sakihama, Y.; Watanabe, M. Investigation of the mechanical strength of cell-plastics fabricated using unicellular green algal cells and varying weight ratios of biodegradable polybutylene succinate. Int. J. Microbiol. Biotechnol. 2020, 5, 159-164.

15. Nakanishi, A.; Iritani, K.; Sakihama, Y.; Ozawa, N.; Mochizuki, A.; Watanabe., M. Construction of cell-plastics as neo-plastics consisted of cell-layer provided green alga Chlamydomonas reinhardtii covered by two-dimensional polymer. AMB Expr. 2020, 10, 112. [CrossRef] [PubMed]

16. Ho, S.-H.; Nakanishi, A.; Kato, Y.; Yamasaki, H.; Chang, J.-S.; Misawa, N.; Hirose, Y.; Minagawa, J.; Hasunuma, T.; Kondo, A. Dynamic metabolic profiling together with transcription analysis reveals salinity-induced starch-to-lipid biosynthesis in alga Chlamydomonas sp. JSC4. Sci. Rep. 2017, 7, 45471. [CrossRef] [PubMed]

17. Lee, H.; Bingham, S.-E.; Webber, A.-N. Function of $3^{\prime}$ non-coding sequences and stop codon usage in expression of the chloroplast psaB gene in Chlamydomonas reinhardtii. Plant Mol. Biol. 1996, 31, 337-354. [CrossRef] [PubMed]

18. Brandrup, J.; Immergut, E.-H.; Grulke, E.-A. Polymer Handbook, 4th ed.; A Wiley-Interscience Publication: Toronto, ON, Canada, 1999; pp. 162-165.

19. Bombelli, P.; Howe, C.-J.; Bertocchini, F. Polyethylene bio-degradation by caterpillars of the wax moth Galleria mellonella. Curr. Biol. 2017, 27, R292-R293. [CrossRef]

20. Sukhija, S.; Singh, S.; Riar, C.-S. Effect of oxidation, cross-linking and dual modification on physicochemical, crystallinity, morphological, pasting and thermal characteristics of elephant foot yam (Amorphophallus paeoniifolius) starch. Food Hydrocoll. 2016, 55, 56-64. [CrossRef] 
21. Yang, C.-Y.; Yen, Y.-Y.; Hung, K.-C.; Hsu, S.-W.; Lan, S.-J.; Lin, H.-C. Inhibitory effects of pu-erh tea on alpha glucosidase and alpha amylase: A systemic review. Nutr. Diabetes 2019, 9, 23. [CrossRef]

22. Ho, S.-H.; Nakanishi, A.; Ye, X.; Chang, J.-S.; Chen, C.-Y.; Hasunuma, T.; Kondo, A. Dynamic metabolic profiling of the marine microalga Chlamydomonas sp. JSC4 and enhancing its oil production by optimizing light intensity. Biotechnol. Biofuels $2015,8,48$. [CrossRef]

23. Kou, Z.; Bei, S.; Sun, J.; Pan, J. Fluorescent measurement of lipid content in the model organism Chlamydomonas reinhardtii. J. Appl. Phycol. 2013, 25, 1633-1641. [CrossRef]

24. Nakanishi, A.; Aikawa, S.; Ho, S.-H.; Chen, C.-Y.; Chang, J.-S.; Hasunuma, T.; Kondo, A. Development of lipid productivities under different $\mathrm{CO}_{2}$ conditions of marine microalgae Chlamydomonas sp. JSC4. Bioresour. Technol. 2014, 152, 247-252. [CrossRef] [PubMed]

25. Ma, N.; Liu, D.; Liu, Y.; Sui, G. Extraction and characterization of nanocellulose from xanthoceras sorbifolia husks. Int. J. Nanosci. Nanoeng. 2015, 2, 43-50. 